\title{
CHANGES IN RONGBUK LAKE AND IMJA LAKE IN THE EVEREST REGION OF HIMALAYA
}

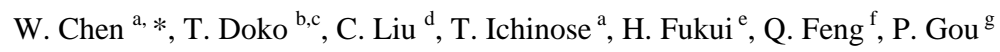 \\ a Graduate School of Media and Governance, Keio University, 5322 Endo, Fujisawa, Japan - chenwb3@gmail.com, \\ tomohiro@sfc.keio.ac.jp \\ b Environment and Information Sciences IV, Yokohama National University, 79-7 Tokiwadai, Hodogaya-ku, Yokohama, Japan - \\ dokochan@sfc.keio.ac.jp \\ ${ }^{c}$ Research Fellow of the Japan Society for the Promotion of Science, 5-3-1 Kojimachi, Chiyoda-ku, \\ Tokyo, Japan - dokochan@sfc.keio.ac.jp \\ ${ }^{\mathrm{d}}$ Institute of Geographical Sciences and Natural Resources Research, Chinese Academy of Sciences, 11A Datun Road, Chaoyang \\ District, Beijing, China - lchuang@igsnrr.ac.cn \\ ${ }^{\text {e }}$ Chubu Institute for Advanced Studies, Chubu University, 1200 Matsumoto-cho, Kasugai, Aichi, Japan - fukui@isc.chubu.ac.jp \\ ${ }^{\mathrm{f}}$ Institute of Remote Sensing and Digital Earth, Chinese Academy of Sciences, No.9 Dengzhuang South Road, Haidian District, \\ Beijing, China - qfeng@ceode.ac.cn \\ ${ }^{\mathrm{g}}$ Institute of Tibetan Plateau Research, Chinese Academy of Sciences, No.16 Lincui Road, Chaoyang District, Beijing, China - \\ gougeng@itpcas.ac.cn
}

KEY WORDS: Change Detection, Climate, Geography, Glaciology, Hydrology, Spatial, Temporal

\begin{abstract}
:
The Himalaya holds the world record in terms of range and elevation. It is one of the most extensively glacierized regions in the world except the Polar Regions. The Himalaya is a region sensitive to climate change. Changes in the glacial regime are indicators of global climate changes. Since the second half of the last century, most Himalayan glaciers have melted due to climate change. These changes directly affected the changes of glacial lakes in the Himalayan region due to the glacier retreat. New glacial lakes are formed, and a number of them have expanded in the Everest region of the Himalayas. This paper focuses on the two glacial lakes which are Imja Lake, located at the southern slope, and Rongbuk Lake, located at the northern slope in the Mt. Everest region, Himalaya to present the spatio-temporal changes from 1976 to 2008. Topographical conditions between two lakes were different (Kruskal-Wallis test, $p<0.05$ ). Rongbuk Lake was located at $623 \mathrm{~m}$ higher than Imja Lake, and radiation of Rongbuk Lake was higher than the Imja Lake. Although size of Imja Lake was larger than the Rongbuk Lake in 2008, the growth speed of Rongbuk Lake was accelerating since 2000 and exceeds Imja Lake in 2000-2008. This trend of expansion of Rongbuk Lake is anticipated to be continued in the 21 st century. Rongbuk Lake would be the biggest potential risk of glacial lake outburst flood (GLOF) at the Everest region of Himalaya in the future.
\end{abstract}

\section{INTRODUCTION}

The Himalaya holds the world record in terms of range and elevation. It is one of the most extensively glacierized regions in the world outside the Polar Regions. Since the last century, most Himalayan glaciers have melted at a rate that ranges from a few meters to several tens of meters per year (Bajracharya et al. 2007). Changes in the glacial regime are indicators of global climate changes.

Glacial meltwater is derived from the ablation of glaciers (ice melting) in one of three positions: supraglacial which means on the ice surface, subglacial at the bed, and englacial which means within the glacier (Bennett and Glasser 2009). Melting occurs whenever there is sufficient heat to turn the ice back into water. This heat can be supplied by solar radiation, friction generated by ice flow, and geothermal heat. The meltwater flows through glaciers, it can be stored in which forms a glacial lake. The glacial lake that its barycentre is included in a glacier outline (on the surface of a glacier) is called supraglacial lake, otherwise it is considered as proglacial lake such as stored in front of a glacier.

Dr. CHEN Wenbo completed her Ph.D. thesis entitled "Comparative study on climatic sensitivities and expansion of glacial lakes on the northern and southern slopes of the
Himalayan summit region over the past three decades (1976 2008)". According to Dr. CHEN Wenbo's thesis on growth and development of the process of glacial lakes, by integrating remote sensing and field trips, we have reasons to believe that as climate warming occurred, Rongbuk glacier, which is located in the north slope of the main peak of the Himalayas-Mount Everest, has been constantly melting. In the course of melting Rongbuk glacier continues, one of the most significant geographical phenomenon are formation and development of glacier lakes. There is a glacial lake located on the Rongbuk glacier. Current status of the lake is one stage of the process that Rongbuk glacier would retreat and further expansion trend of the lake would be characterized as development process. The lake is located on the water body of the Rongbuk moraine, and anticipated to grow more extensively; however, there is "no official record of the name" yet.

In the view of the geographical position of this water body, considering the cause and development of this lake, the lake should have an official name. As a member of the Rongbuk family- for instance, from Rongbuk temple to Rongbuk glacier, as well as Rongbuk moraine, and Rongbuk U-shaped Valley, her name-Rongbuk Lake-better reflects the northern slopes of Mt. Everest integrating geographical environment of the ecological system relationships. Of course, an official naming

\footnotetext{
* Corresponding author.
} 
of the lake needs to be formally determined by the relevant departments of the nation; hence we will follow up the work. From the perspective of geographic science and global change research, we, the authors of this paper, propose to give this particular water bodies a formal name-"Rongbuk Lake".

This study focuses on time-series changes of two glacial lakes in Mt. Everest region, Himalaya (Figure 1). One is Imja Lake, which is located at the southern slope of Mt. Everest (Nepal), and another is Rongbuk Lake, which is located at the northern slope of Mt. Everest (China).

Imja Lake (lat./long. 27 53'54.45"/ 86 55'20.74", altitude 5010 m) appeared in 1960s, which was composed of several smaller supraglacial ponds. Because Imja Lake expanded faster, it has been identified as one of the lakes displaying the greatest potential for a glacial lake outburst flood (GLOF) in the Nepalese part of the Himalaya (Mool et al. 2001).

On the other hand, Rongbuk Lake appeared in 1990s (lat./long. $28^{\circ} 6^{\prime} 48^{\prime \prime} / 86^{\circ} 51^{\prime} 47.35^{\prime \prime}$, altitude $5223 \mathrm{~m}$ ). It was a very smaller supraglacial pond which was located in the middle of morainecovered Rongbuk glacier. Rongbuk Lake has not been marked in any map due to the new appeared lake in Mt. Everest region, Himalaya.

The objectives of this study were (a) to analyze spatio-temporal differences in the trends of changes in Imja Lake and Rongbuk Lake during four time periods, i.e., 1976, 1992, 2000, and 2008 and (b) to examine whether the topographic conditions differ between the two glacial lakes.

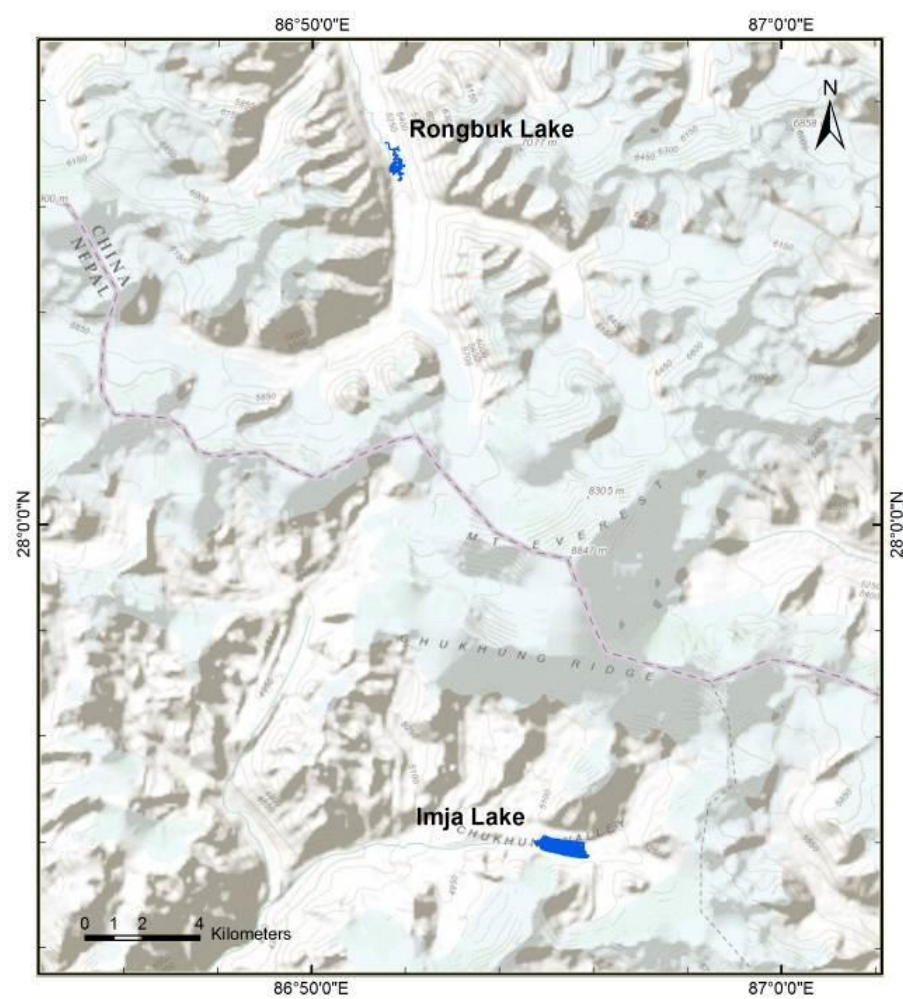

Figure 1 Rongbuk Lake and Imja Lake in Mt. Everest region, Himalaya (Basemap source: ESRI)

\section{MATERIALS AND METHODS}

\subsection{Fieldwork}

Dr. CHEN Wenbo and her team members visited the Himalayan region for field survey in 2008 and 2012 as follows.

In 2008, Dr. Wenbo CHEN visited Imja Lake as a member of Keio University. Keio University of Japan, Department of National Parks and Wildlife Conservation (DNPWC), and International Center for Integrated Mountain Development (ICIMOD) have signed memorandum of understanding to undertake impact of climate change study called "Imja Glacial Lake Outburst Flood Monitoring", leaded by Prof. Hiromichi Fukui, Keio University (current professor of Chubu University). The two other organizations, involved in the research, are National Agricultural Research Council (NARC) of Japan, and Nepal Research Education Network (NREN). This research has been carried out from 2007 to March, 2009 as part of the "Digital Asia" Project, which is one of the Academic Frontier Projects adopted in academic year 2004 and supported by The Ministry of Education, Culture, Sports, Science and Technology, Japan (MEXT) with financial assistance and infrastructure. The collaboration brought to the successful establishment of unique monitoring device for real time monitoring in Himalaya. In November 2007 and April to May 2008, field survey team from Keio University and NARC installed a couple of the unique monitoring device called Field Server (NARC product) covered some part of the Himalaya regions. Presently, several field servers with the digital camera have been installed. Two of them have been placed at the end of moraine of the Imja Lake and at the Island peak site. Others are at Namche areas. The field server is a monitoring device embedded with a camera to capture real time images. It is required to set up the wireless LAN and use the Internet technology to transmit the meteorological data and images, capturing from field servers, to the server in Japan.

In 2012, as a part of activities during the APN - CODATA Joint Workshop on Open Access to Global Change Data and Information in Asia-Pacific Region (23-31 May 2012, Xining/Qinghai - Lhasa/Tibet, China), Dr. CHEN Wenbo, Prof. LIU Chuang, Dr. FENG Qiang, Mr. GOU Peng, Dr. Tomoko Doko, and other participants had a fieldwork in the Tibet plateau in the Himalaya. All participants visited Nam Co Lake, Qinghai Lake Observing Station during the workshop. The main part of the workshop was held in Lhasa, Tibet. The workshop was leaded by Prof. LI Guoqing, and cosponsored by APN, CODATA/ICSU, CN-CODATA, IRDR/ ICSU, CEODE (CAS), IRSA (CAS), ITPCAS (CAS), and IGSNRR (CAS) (Li, 2012). After the workshop, Dr. CHEN Wenbo, Prof. LIU Chuang, Dr. FENG Qiang, and Mr. GOU Peng took additional field surveys to Rongbuk Lake.

\subsection{Data Sources}

Satellite images with minimal obstruction by clouds and snow coverage were used in this study. These images were the Landsat MSS from December 1976, with a spatial resolution of $60 \mathrm{~m}$, the Landsat TM from November 1992, with a spatial resolution of $30 \mathrm{~m}$, the Landsat ETM+ from October 2000, with a spatial resolution of $30 \mathrm{~m}$, and the ASTER from January 2008 , with a spatial resolution of $15 \mathrm{~m}$. For the terrain analysis, ASTER Global DEM data were downloaded from the ASTER GDEM website. 


\subsection{Identification of Glacial Lakes}

The normalized difference water index (NDWI) was calculated to allow identification of water bodies from the satellite images. NDWI is defined as the difference of reflectance observed in the green band and the NIR band divided by the sum of the two reflectance values (McFeeters 1996). A model of the terrain was developed based on a digital elevation model (DEM) derived from the ASTER GDEM data. Based on the previous field work by the authors in the Himalaya and Tibet, China, it was recognized that the angle of inclination that allowed drainage of melt water had gradients greater than $10^{\circ}$. Study in Bhutan (Reynolds 2000) and study in China and Nepal (Quincey et al. 2007) reported similar observations. Thus, a threshold value of a ground angle of inclination of $10^{\circ}$ (maximum) was adopted in this study (Chen et al. 2013a). The boundaries of two glacial lakes were identified by integrating the NDWI and angle of inclination criteria. If the satellite imageries are covered by shadow, DSGL method (Chen et al. 2013b) is effective to detect glacial lakes. However, as the satellite imageries we used are fortunately not covered by shadow, the DSGL method was not used in this study. The satellite imagery analysis and data processing were performed using $\mathrm{ENVI}^{\circledR} 4.7$.

\subsection{Changes in the Two Glacial Lakes}

We calculated surface areas, growth rate, and growth speed based on the method developed by Chen et al. 2013 as follows.

First, the surface areas of Imja Lake and Rongbuk Lake during the four time periods in the years 1976, 1992, 2000, and 2008 were calculated in $\mathrm{m}^{2}$ and coded as $A_{\text {lake.year }}$. The variable lake was coded as either "Imja" or "Rongbuk", and the year was coded as 1976, 1992, 2000, or 2008. For example, $A_{\text {Imja.1976 }}$ denotes the surface area of Imja Lake in 1976.

Second, based on the surface areas of the glacial lakes, three indices were developed: (1) the growth rate of the area of a particular lake compared to its area in the originating period was defined as $G R_{\text {a.lake.year }}(\%)$, for example, $G R_{\text {a.Imja.1992 }}=$ $A_{\text {Imja.1992 }} / A_{\text {Imja.1976 }} * 100$, whereas $G R_{\text {a.Imja.1976 }}=100$, as the originating period was 1976 for Imja Lake. For the case of Rongbuk Lake, the originating period was 1992; (2) the growth rate of the area of a lake compared to that of the lake in the preceding time interval was defined as $G R_{\text {blakeyear }}(\%)$, for example, $G R_{\text {b.Imja.2008 }}=A_{\text {Imja.2008 }} / A_{\text {Imja. } 2000} * 100$; and (3) the growth speed of a lake was defined as the expanded area per year between consecutive time periods and was coded as $G S$ lake.year $\left(\mathrm{m}^{2} /\right.$ year $)$, for example, $G S_{\text {Imja. } 2008}=\left(A_{\text {Imja.2008 }}-\right.$

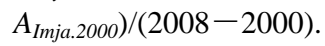

\subsection{Topographic Conditions}

Watersheds are the area of land where all of the water that is under it or drains off of it goes into the same place along a stream, wetland, lake or river (USEPA 2012). A watershed is the upslope area that contributes flow crossing county, state, and national boundaries to a given location at the downslope. It can be delineated from a DEM by computing the flow direction to determine the contributing area. Digital elevation models provide good terrain representation from which the watersheds can be derived automatically using GIS technology (Brown and Schreier 2007). Watersheds were calculated using the ASTER GDEM data in $\operatorname{ArcMap}^{\circledR} 10$.

To address the differences in topographic conditions between the two lakes, four topographical variables, which are altitude, angle of inclination, aspect, and radiation, were calculated. The watershed was used as the base unit to aggregate the abovementioned topographic information.

The distribution of the four topographical variables was examined using boxplots. Descriptive statistics were calculated for each variable. The topographical differences between Imja Lake and Rongbuk Lake were tested using the Kruskal-Wallis test $(p<0.05)$. These statistical analyses were conducted using the software R, version 2.14.0.

\section{RESULTS}

\subsection{Fieldwork}

The routes and photographs of Imja Lake and Rongbuk Lake are illustrated in Figure 2 and Figure 3 respectively. In 2008, we accessed to Imja Lake from Lukla, Nepal. In 2012, we accessed to Rongbuk Lake from Xining, China.

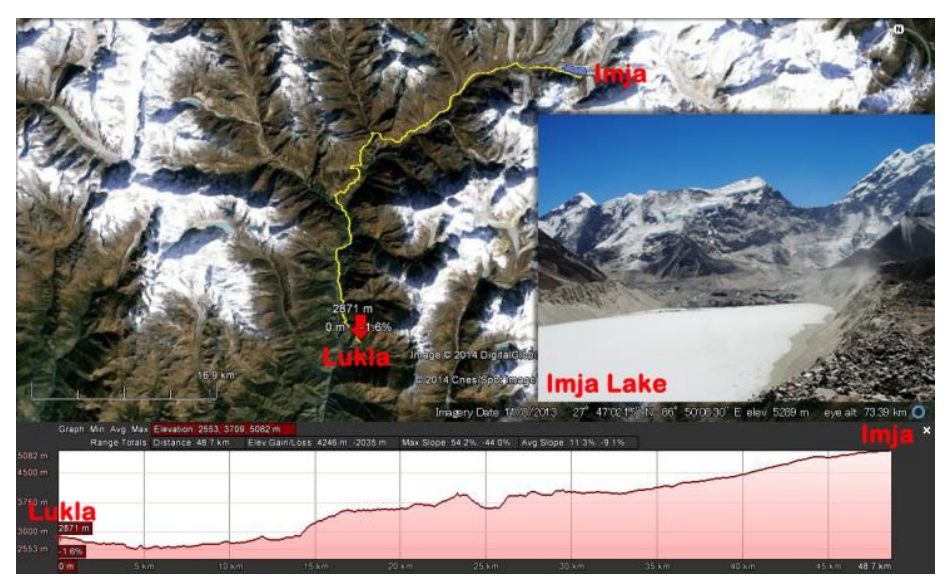

Figure 2 Fieldwork route to Imja Lake

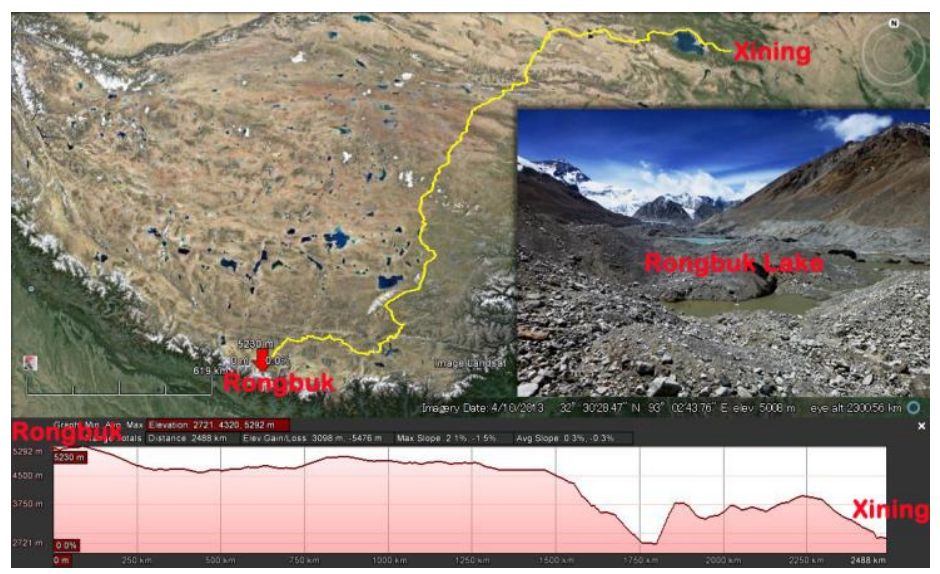

Figure 3 Fieldwork route to Rongbuk Lake 


\subsection{Spatio-temporal analysis}

Table 1 presents the summary of time-series changes of surface areas, growth rate, and growth speed of Rongbuk Lake and Imja Lake. Figure 4 shows the time-series changes of two lakes in the map. In general, both Rongbuk Lake and Imja Lake have been increasing during the past thirty-two years (Table 1 and Figure 4). The surface area of Rongbuk Lake expanded by $250,804 \mathrm{~m}^{2}$ from $1992\left(3,051 \mathrm{~m}^{2}\right)$ to $2008\left(253,855 \mathrm{~m}^{2}\right)$. The one of Imja Lake expanded by $574,104 \mathrm{~m}^{2}$ from $1976(284,411$ $\mathrm{m}^{2}$ ) to $2008\left(858,515 \mathrm{~m}^{2}\right)$.

However, the growth rate $\left(G R_{\text {a.lake.year }}\right)$ was very different between two lakes. When the size of Imja Lake in 1976 was $100 \%$, the growth rate of Imja Lake in 1992, 2000, and 2008 was $199 \%, 255 \%$, and $302 \%$, respectively. That means by 2008 the Imja Lake expanded 3 times as large as what it was in the beginning. On contrary, Rongbuk Lake's growth rate was incredible. When the size of Rongbuk Lake in 1992 was $100 \%$, the growth rate in 2000 and 2008 were 2,613\% and 8,320\%, respectively. The Rongbuk Lake in 2008 was 83 times as large as the size in 1992 .

Although the size of Imja Lake has been steadily expanding over years, Rongbuk Lake's expansion rate was not stable. When the growth rate was compared to the preceding year $\left(G R_{\text {b.lakeyear }}\right)$, the growth rate of Imja Lake between 1992-1976, 2000-1992, 2008-2000 was $199 \%, 128 \%, 119 \%$, respectively. However, the growth rate of Rongbuk Lake between 2000-1992, and 2008-2000 was 2,613\% and $318 \%$, respectively. During the period of 1992 to 2000, the Rongbuk Lake was drastically enlarged. Moreover, it continued to grow up with higher growth rate $(318 \%)$ compared to the one of Imja Lake (119\%) between 2000 and 2008.

Growth speed, $G S_{\text {lake.year }}$ ( $\mathrm{m}^{2} /$ year), of the Rongbuk Lake was slower $\left(9,586 \mathrm{~m}^{2} /\right.$ year) than Imja Lake $\left(19,626 \mathrm{~m}^{2} /\right.$ year) during the period of 1992-2000. Nevertheless, the recent growth speed during 2000-2008 demonstrated that melting speed of Rongbuk Lake became faster $\left(21,765 \mathrm{~m}^{2} /\right.$ year $)$ than Imja Lake $\left(16,769 \mathrm{~m}^{2} /\right.$ year$)$.

\begin{tabular}{|c|c|c|c|}
\hline & & Rongbuk Lake & Imja Lake \\
\hline \multirow{4}{*}{ Area $\left(\mathrm{m}^{2}\right)$} & 1976 & 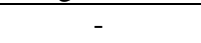 & 284,411 \\
\hline & 1992 & 3,051 & 567,360 \\
\hline & 2000 & 79,736 & 724,365 \\
\hline & 2008 & 253,855 & 858,515 \\
\hline \multirow{4}{*}{$\begin{array}{l}G R_{\text {alake.year }} \\
\quad(\%)\end{array}$} & $G R_{\text {alake } 1976}$ & - & 100 \\
\hline & $G R_{\text {a.lake. } 1992}$ & 100 & 199 \\
\hline & $G R_{\text {a.lake. } 2000}$ & 2,613 & 255 \\
\hline & $G R_{\text {a.lake.2008 }}$ & 8,320 & 302 \\
\hline \multirow{4}{*}{$\begin{array}{c}G R_{\text {b.lake.year }} \\
\quad(\%)\end{array}$} & $G R_{\text {b.lake.1976 }}$ & - & - \\
\hline & $G R_{\text {b.lake. } 1992}$ & - & 199 \\
\hline & $G R_{\text {b.lake.2000 }}$ & 2,613 & 128 \\
\hline & $G R_{\text {b.lake.2008 }}$ & 318 & 119 \\
\hline \multirow{3}{*}{$\begin{array}{l}G S_{\text {lake.year }} \\
\left(\mathrm{m}^{2} / \text { year }\right)\end{array}$} & $G S_{\text {lake. } 1992}$ & - & 17,684 \\
\hline & $G S_{\text {lake. } 2000}$ & 9,586 & 19,626 \\
\hline & $G S_{\text {lake. } 2008}$ & 21,765 & 16,769 \\
\hline
\end{tabular}

Table 1. Area, Growth rate, and Growth speed between
The geographic locations of glaciers and glacial lakes are illustrated in Figure 5 for Imja Lake and Figure 6 for Rongbuk Lake. Both of two lakes were supraglacial lakes at the beginning. Both lakes had sources of water from three glaciers. For instance, as a case of Imja Lake, there were Lhotse Glacier, Imja Glacier, and Ambulapcha Glacier to the north. Similarly, Rongbuk Lake had East Rongbuk Glacier, Central Rongbuk Glacier, and West Rongbuk Glacier, in the direction of the north. However, the scale of those glaciers was different. The total area of glaciers of Imja Lake was $6.4 \mathrm{~km}^{2}$ and the one of Rongbuk Lake was $48.2 \mathrm{~km}^{2}$.
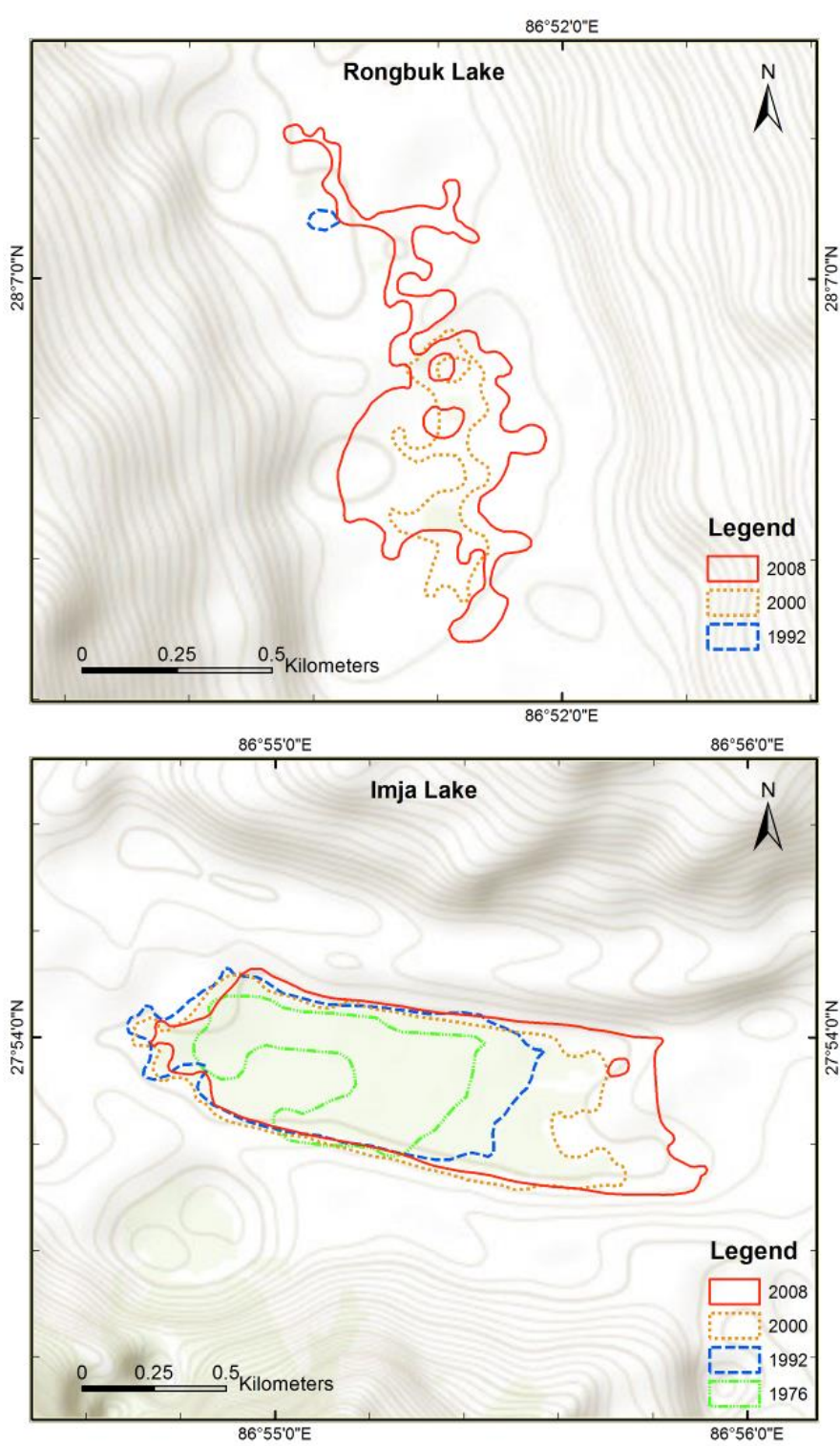

Figure 4. Map of time-series changes of Rongbuk Lake and Imja Lake (Basemap source: ESRI)

Rongbuk Lake and Imja Lake 




Figure 5. Imja Lake and glaciers connected to Imja Lake. The light yellow presents glaciers and blue presents Imja Lake.

(Basemap source: Google Earth)

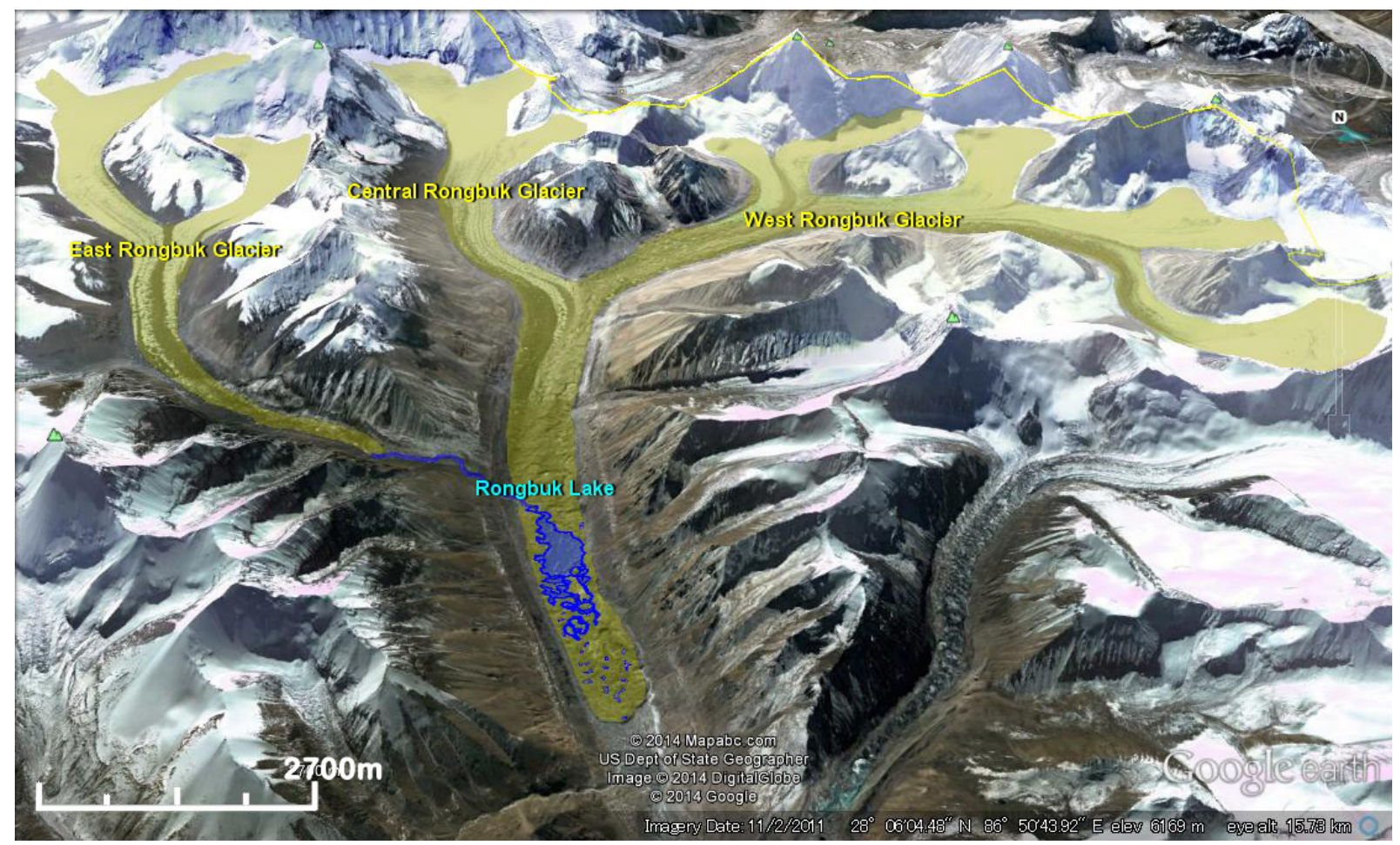

Figure 6. Rongbuk Lake and glaciers connected to Rongbuk Lake. The light yellow presents glaciers and blue presents Rongbuk Lake. (Basemap source: Google Earth)

\subsection{Topographic conditions}

Kruskal-Wallis test proved that all topographic conditions between Imja Lake and Rongbuk Lake differed $(p<2.2 \mathrm{e}-16)$. Table 2 and Figure 7 show the descriptive statistics and boxplots of topographic conditions, respectively. The mean aspect for both lakes were south to south-west direction. There was large difference between mean altitudes of two lakes; the mean altitude of Rongbuk Lake was $623 \mathrm{~m}$ higher than the one of Imja Lake. The elevation was higher in Rongbuk Lake than Imja Lake. In general, the angle of inclination of Imja Lake was larger than the Rongbuk Lake. The Rongbuk Lake received more radiation than the Imja Lake. 

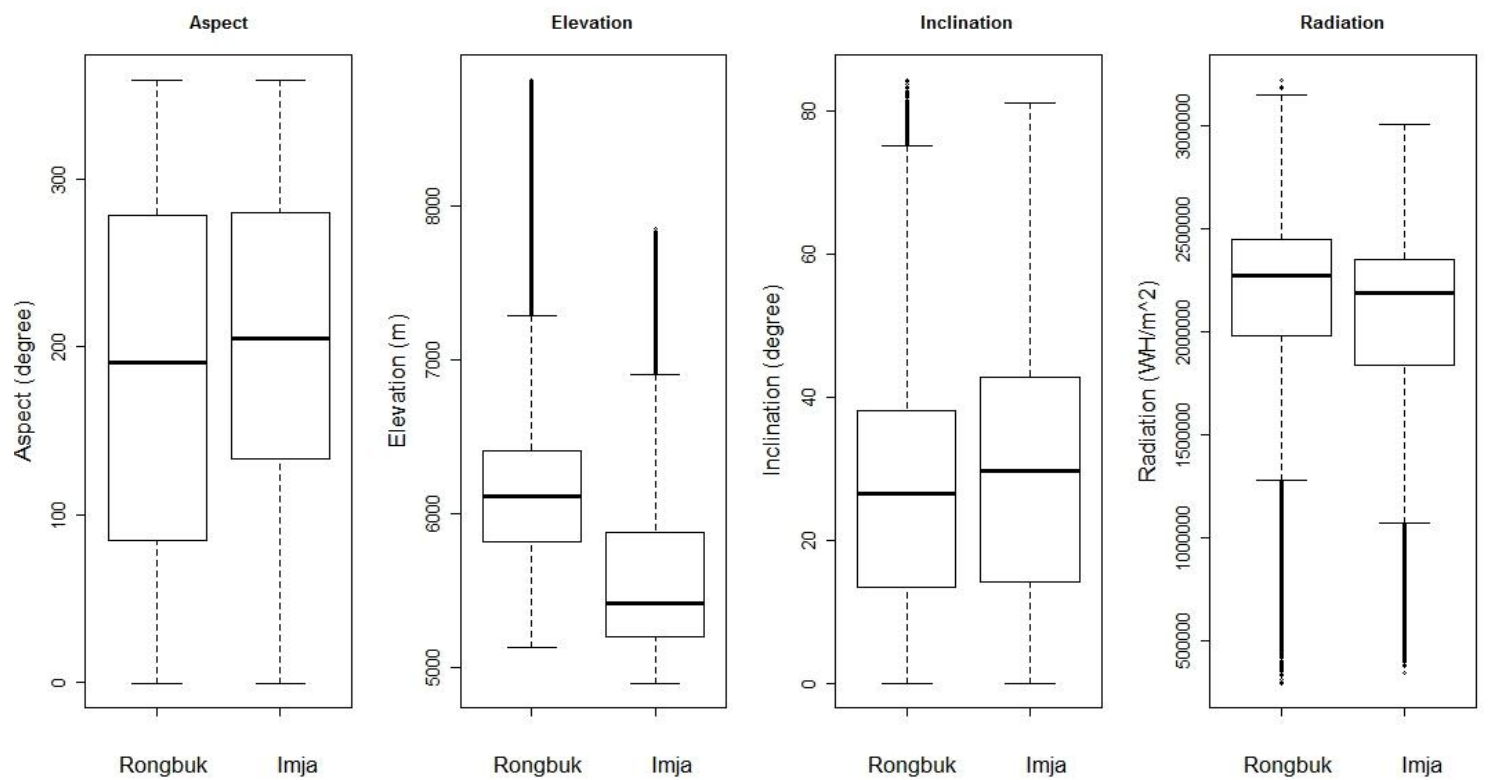

Figure 7. Boxplots of topographic conditions of Rongbuk Lake and Imja Lake

\begin{tabular}{|cc|c|c|}
\hline Parameter & Lake & Rongbuk Lake & Imja Lake \\
\hline & Min & -1.0 & -1.0 \\
Aspect (degree) & Mean & 184.2 & 199.0 \\
& Max & 359.9 & 359.9 \\
& SD & 109.7 & 98.8 \\
\hline & Min & 5127 & 4893 \\
Altitude (m) & Mean & 6139 & 5516 \\
& Max & 8825 & 7850 \\
& SD & 489 & 580 \\
\hline & Min & 0.00 & 0.00 \\
inclination & Mean & 26.83 & 29.72 \\
$($ degree $)$ & Max & 84.47 & 81.21 \\
& SD & 15.58 & 17.58 \\
\hline & Min & 297000 & 347800 \\
Radiation & Mean & 2174000 & 2057000 \\
$\left(\right.$ WH $\left./ m^{2}\right)$ & Max & 3221000 & 3002000 \\
& SD & 387552 & 451994 \\
\hline
\end{tabular}

Table 2. Topographic condition in the watersheds of Rongbuk Lake and Imja Lake

\section{DISCUSSION}

\subsection{Conditions of two glacial lakes}

Our results suggested that both glacial lakes of Rongbuk Lake and Imja Lake had increased in past decades. The size of Imja Lake in 2008 was $858,515 \mathrm{~m}^{2}$, which was larger than the Rongbuk Lake that had $253,855 \mathrm{~m}^{2}$ (Table 1). Hence, as pointed out by other scientists (Mool et al. 2001, Chen et al. 2013a) and local authorities, our study supports that Imja Lake should be identified as one of the lakes displaying the bigger potential for a glacial lake outburst flood (GLOF) in the Nepalese part of the Himalaya.
However, our results (Table 1) indicate that the Rongbuk Lake could carry a significant risk of GLOF in future. As described in the introduction, this lake does not have an official name until this paper publishes and is not illustrated in any map as a lake. Till today, the Rongbuk Lake has never been paid attention by any organizations. Nevertheless, our results suggested that the growth rate of Rongbuk Lake was too fast to be simply ignored; that is $2,613 \%$ compared to the size of Rongbuk Lake in 1992. Also, it was found that recent growth speed of Rongbuk Lake exceeded the same of Imja Lake. From 2000 to 2008, the growth speed of Rongbuk Lake was 21,765 $\mathrm{m}^{2} /$ year, while the speed of Imja Lake was $16,769 \mathrm{~m}^{2} / \mathrm{year}$.

\subsection{Possible mechanisms for expansion of glacial lakes}

The reason why both surface areas of Rongbuk Lake and Imja Lake had increased in the past decades could be explained by the global climate changes. According to the IPCC first assessment report in 1990 (Houghton et al. 1990), the mean global temperature has increased by $0.3^{\circ} \mathrm{C}$ to $0.6^{\circ} \mathrm{C}$ over the last 100 years, and the global temperature is predicted to continue rising during this century, especially in the high altitude. It is estimated that $1^{\circ} \mathrm{C}$ rise in temperature will cause alpine glacier worldwide to shrink as much as $40 \%$ in area and more than $50 \%$ in volume as compared to 1850 (IPCC 2001a, b). As a result of temperature rise, glaciers had been retreat. Some specific studies implemented in both northern and southern slope of the Himalaya. In the northern slope, Tibet in China, area of glaciers has decreased, and this change trends to continue within the coming decades (Burroughs 2003; Chen et al. 2007; Li et al. 2008; Ma et al. 2010). On the other hand, in the southern slope, glaciers are receding at an alarming rate (Bolch et al. 2008). Glaciers melting directly influenced the glacial lakes' changes.

However, global climate change itself cannot explain why the Rongbuk Lake suddenly started to appear and continuously and significantly has expanded recently. We attribute these phenomena to two possible reasons as follows: (1) time lags 
effects, and (2) potential hazardous location of the Rongbuk Lake that could expand this lake more than other glacial lakes.

\subsection{1."Time lags" effects to respond to climate change:}

Climatic parameters change in directional way through time, and it is known that this directional change of climate profound effects on the structure of biological communities (Davis et al. 1986). Some organisms track climate closely, reacting to conditions each year, while others respond so slowly that only long-term climatic trends have any observable impacts (Davis et al. 1986). This effect is called a "time lag" that the target system needs time to respond to the climate change.

There are not so many previous studies on hydrochemical responses to climate change at high altitude. One of these studies was conducted by Williams et al. (1996). They studied the response of climate change at the high-elevation catchment in the Rocky Mountains, USA, and concluded that "small changes in climate parameters may cause large changes in the hydrochemistry of alpine streams. The changes in climate at Niwot Ridge are not in synchrony with lowland warming in the Great Plains to the east and serve as a reminder that climate in alpine areas is driven by local conditions and may be asynchronous with regional and global climate trends".

The responses of biological communities, such as plants, birds, mammals, insects, etc., to climate change are relatively studied (e.g. Davis et al. 1986). But, to the authors' knowledge, these responses of glacial lakes and glaciers to climate change have not been revealed well. For example, whether time lag effects occur to glacial lakes or how many years should be taken to respond to the global or local climate changes are not known.

Although we need to have more evidence to conclude responses of glacial lakes and time lag to climate change, we would like to propose one of possibilities that time lag of Rongbuk Lake was longer than the one of Imja Lake due to the topographical conditions, as our new hypothesis.

\subsubsection{Potential hazardous location of the Rongbuk Lake:}

Our results revealed the topographic conditions, e.g. aspect, elevation, inclination, and radiation, between the two lakes were different (Kruskal-Wallis test, $p<0.05$ ). Rongbuk Lake receives more radiation than Imja Lake does, which is because Rongbuk Lake is located at the higher altitude. The difference in altitude is considered to have influenced the development of the glacial lakes. Generally, temperature falls at a rate of about $0.65^{\circ} \mathrm{C}$ with every $100 \mathrm{~m}$ rise in altitude (Foster 1982; Goudie 1983, 1992; Luhr 2003). We hypothesize that due to high altitude, time lag became longer in Rongbuk Lake than Imja Lake. Hence, Rongbuk Lake did not start expanding in the 1970s, though Imja Lake started to expand in the 1970s. On contrary, higher radiation at the Rongbuk Lake suggests that it is easier to expand faster than the Imja Lake once expansion starts.

Additionally, the total area of glaciers of Rongbuk Lake was much bigger (approximately $48.2 \mathrm{~km}^{2}$ ) than the glaciers of Imja Lake (approximately $6.4 \mathrm{~km}^{2}$ ), which means that the Rongbuk Lake is located at the potentially hazardous location which could occur GLOF easier.

\subsection{Risk of Rongbuk Lake and Imja Lake}

The common point of the two lakes is that they were supraglacial lakes at the beginning; it means they appeared on the glacier which was covered by moraines. Along with expansion and movement of water due to the glacier's melting, Imja Lake had become a proglacial lake at the exposed end moraines of glaciers (Figure 5). Imja Lake has been identified a potential risk lake for GLOF by local authority because of faster expansion. The current status of Rongbuk Lake is similar to an initial stage of Imja Lake in 1960s. Even though Rongbuk Lake is a smaller supraglacial lake right now, the growth speed was becoming faster since 21 st century. It could be the second Imja Lake according to its expansion speed on the northern slope at the Everest region. Moreover, the magnitude of Rongbuk Lake will exceed to Imja Lake in the future, because there are richer resources for water accumulation at the back of it from East Rongbuk Glacier, Central Rongbuk Glacier, and West Rongbuk Glacier (Figure 6). If the temperature will be continually increasing, those three Rongbuk glaciers will tend to continue retreating in the future. Thus, Rongbuk Lake would be the potentially most dangerous lake for the GLOF in the future, which could endanger life and property in the downstream regions of the mountain. Both Rongbuk Lake and Imja Lake should be monitored and regularly mapped in order to give an early warning to the local communities.

\section{ACKNOWLEDGEMENTS}

The authors are thankful to the Global Earth Observation Grid, Japan, for providing the ASTER data via the GEO Grid project, which was developed with the goal of providing an E-Science infrastructure to the worldwide earth sciences community. We thank Institute of Remote Sensing and Digital Earth, Chinese Academy of Sciences, Institute of Tibetan Plateau Research, Chinese Academy of Sciences, and Nepal Research Education Network (NREN) for great assistance for field survey in the Himalaya. Funding for this research was provided by The Ministry of Education, Culture, Sports, Science and Technology, Japan (MEXT), APN, CODATA/ICSU, CN-CODATA, IRDR/ ICSU, CEODE (CAS), IRSA(CAS), ITPCAS(CAS), and IGSNRR(CAS), the Research Promotion Fund in Remembrance of Mori Taikichiro in 2011, 2012, and 2013 of Keio University, and Kurita Water and Environment Foundation in 2013 (13B128, 2013).

\section{REFERENCES}

Bajracharya, S.R., Mool, P.K., \& Shrestha, B.R., 2007. Impact of Climate Change on Himalayan Glaciers and Glacial Lakes: Case Studies on GLOF and Associated Hazards in Nepal and Bhutan. Kathmandu: International Centre for Integrated Mountain Development (ICIMOD).

Bennett, M.R., \& Glasser, N.F., 2009. Glacial Geology. Chichester: John Wiley \& Sons Ltd.

Bolch, T., Buchroithner, M., Pieczonka, T., \& Kunert, A., 2008. Planimetric and volumetric glacier changes in the Khumbu Himal, Nepal, since 1962 using Corona, Landsat TM and ASTER data. Journal of Glaciology, 54, pp. 592-600.

Brown, S., \& Schreier, H., 2007. Introducing Innovations into Watershed Management. In M.F. Price (Ed.), Mountain Area Research \& Management (pp. 99-111). London: Earthscan. 
Burroughs, W., 2003. Climate: Into the 21st Century. Cambridge: Cambridge University Press.

Chen, W., Doko, T., Fukui, H., \& Yan, W., 2013a. Changes in Imja Lake and Karda Lake in the Everest Region of Himalaya. Natural Resources, 4, pp. 449-455.

Chen, W., Fukui, H., Doko, T., and Gu, X., 2013b. Improvement of Glacial Lakes Detection under Shadow Environment Using Aster Data in Himalayas, Nepal. Chinese Geographical Science, 23 (2), pp. 216-226.

Chen, X., Cui, P., Li, Y., Yang, Z., \& Qi, Y., 2007. Changes in glacial lakes and glaciers of post-1986 in the Poiqu River basin, Nyalam, Xizang (Tibet). Geomorphology, 88, pp. 298-311.

Davis, Margaret Bryan, 1986. Climatic Instability, Time Lags, and Community Disequilibrium, In (TJ Case and J Diamond eds.), Community Ecology, pp. 269-284. Harper \& Row.

Foster, R.J., 1982. Earth science: Benjamin/Cummings Pub. Co.

Goudie, A., 1983. Environmental Change: Clarendon Press.

Goudie, A., 1992. Environmental Change. Oxford: Clarendon Press.

Houghton, J.T., Jenkins, G.J., \& J.J., E., 1990. Climate Change 1992: The IPCC Scientific Assessment. Cambridge: Cambridge University Press.

IPCC, 2001a. IPCC Third Assessment Report - Working Group I: The Scientific Basis: CAMBRIDGE UNIVERSITY PRESS.

IPCC, 2001b. IPCC Third Assessment Report - Working Group II: Impacts, Adaptation and Vulnerability: CAMBRIDGE UNIVERSITY PRESS.

Li, G., 2012. Final Report CBA2011-16NSY-Li: Demonstration Study on Advancing Global Change Research Approaches Based on Inter-Agency Collaboration and Data Infrastructure of GENESI and GeoBrain, http://www.apngcr.org/resources/items/show/1694 (18 May 2014).

Li, X., Cheng, G., Jin, H., Kang, E., Che, T., Jin, R., Wu, L., Nan, Z., Wang, J., \& Shen, Y., 2008. Cryospheric change in China. Global and Planetary Change, 62, pp. 210-218.

Luhr, J.F., 2003. Earth. New York: DK Pub.

Ma, L., Tian, L., Pu, J., \& Wang, P., 2010. Recent area and ice volume change of Kangwure Glacier in the middle of Himalayas. Chinese Science Bulletin, 55, pp. 2088-2096.

McFeeters, S.K., 1996. The use of the Normalized Difference Water Index (NDWI) in the delineation of open water features. International Journal of Remote Sensing, 17, pp. 1425-1432.

Mool, P.K., Bajracharya, S.R., \& Joshi, S.P., 2001. Inventory of Glaciers, Glacial Lakes and Glacial Lake Outburst Floods Monitoring and Early Warning Systems in the Hindu KushHimalayan Region, Nepal. In. Kathmandu: International Centre for Integrated Mountain Development (ICIMOD).
Quincey, D.J., Richardson, S.D., Luckman, A., Lucas, R.M., Reynolds, J.M., Hambrey, M.J., \& Glasser, N.F., 2007. Early recognition of glacial lake hazards in the Himalaya using remote sensing datasets. Global and Planetary Change, 56, pp. $137-152$.

Reynolds, J.M., 2000. On the formation of supraglacial lakes on debris-covered glaciers. In M. Nakawo, C.F. Raymond \& A. Fountain (Eds.), Workshop on Debris-Covered Glaciers (pp. 153-161). Seattle, Washington, USA: International Association of Hydrological Sciences (IAHS).

USEPA, 2012. What is a Watershed? In. Washington, DC: U.S. Environmental Protection Agency.

Williams, Mark W, Losleben, Mark, Caine, Nel, and Greenland, David, 1996. Changes in climate and hydrochemical responses in a high-elevation catchment in the Rocky Mountains, USA. Limnology and Oceanography, 41, pp. 939-946. 